\title{
Growth rates of ten diatom species from the Barents Sea at different irradiances and day lengths*
}

\author{
Mona Gilstad, Egil Sakshaug \\ Trondhjem Biological Station, The Museum, University of Trondheim, Bynesveien 46, N-7018 Trondheim, Norway
}

\begin{abstract}
Nutrient-sufficient cultures of 10 arctic diatom species were grown at a combination of 9 irradiances and 4 day lengths at $-0.5^{\circ} \mathrm{C}$. The growth rate was calculated on the basis of in vivo fluorescence measurements. Maximum recorded growth rates ranged from $0.41 \mathrm{~d}^{-1}$ (Amphiprora sp.) to $0.60 \mathrm{~d}^{-1}$ (Thalassiosira antarctica and T. bulbosa). Growth rates generally increased with irradiance up to 50 or $70 \mu \mathrm{mol} \mathrm{m} \mathrm{m}^{-2} \mathrm{~s}^{-1}$, above which they depended mainly on day length. The day length response of light-saturated cultures was satisfactorily described by a rectangular hyperbola.
\end{abstract}

\section{INTRODUCTION}

Seasonal variations in irradiance and day length are the largest and most predictable environmental fluctuations that arctic phytoplankton experience. These variations are enhanced by ice cover. This, in combination with generally low temperatures, forms an extreme environment. One might therefore expect phytoplankton to have evolved particular adaptations to varying irradiance, day length, and low temperature.

Numerous papers have documented the effect of light, nutrient supply, salinity, and temperature upon phytoplankton growth at high latitudes (Grant \& Horner 1976, Neori \& Holm-Hansen 1982, Harrison \& Platt 1986, Spies 1987). Some authors have focussed on the effects of the light regime on the growth of polar phytoplankton (Palmisano \& Sullivan 1985, Sakshaug \& Holm-Hansen 1986, Hegseth 1989). Recorded growth rates for natural phytoplankton communities at low temperatures are $<0.92 \mathrm{~d}^{-1}$ (Durbin 1974, Palmisano \& Sullivan 1982, Jacques 1983, Spies 1987).

We present here growth rates for nutrient-saturated phytoplankton cultures grown at combinations of different irradiances and day lengths at $-0.5^{\circ} \mathrm{C}$. Ten diatom species were selected, comprising 4 arctic-boreal species, 3 obligate arctic species, and 3 epontic species. Such data are useful for calibration of empirical models for prediction of the light-dependent growth rate.

\footnotetext{
- Contribution No. 244 from Trondhjem Biological Station
}

\section{MATERIAL AND METHODS}

The 10 diatom species were collected in the Barents Sea in the summers of 1984 and 1985, and were isolated by Professor Eystein Paasche (no. 1) and Dr Erik Syvertsen (nos. 2 to 10) (Table 1).

Species 1 to 7 may be divided into an arctic-boreal group (Nos. 1 to 4) and a group of obligate arctic species (nos. 5 to 7; Syvertsen pers. comm.). Nos. 8 to 10 are epontic.

Stock and experimental cultures were grown at -0.5 $\pm 0.2^{\circ} \mathrm{C}$ in filtered seawater collected at $30 \mathrm{~m}$ depth off the Trondhjem Biological Station, Norway (salinity $=$ ca $33 \mathrm{ppt}$. The water was enriched with the ' $\mathrm{f}$ ' medium of Guillard \& Ryther (1962) at half strength. Stock cultures were grown at a scalar irradiance (PAR) of $120 \mu \mathrm{mol}$

Table 1. Diatoms investigated

\begin{tabular}{|ll|}
\hline Species & Clone \\
\hline 1. Thalassiosira antarctica Comber var. borealis & PMTa1 \\
2. Thalassiosira nordenskioeldii Cleve & PMTn3 \\
3. Porosira glacialis (Grunow) Cleve & PMPg1 \\
4. Nitzschia delicatissima Cleve & PMNd1 \\
5. Thalassiosira bulbosa Syvertsen & PMTbu3 \\
6. Thalassiosira bioculata (Grunow) Ostenfeld & PMTbi2 \\
7. Chaetoceros furcellatus Bailey & PMCf1 \\
8. Amphiprora sp. & PMis1 \\
9. Nitzschia vanhoeffenii Gran & PMis2 \\
10. Nitzschia grunowii Hasle & PMis4 \\
\hline
\end{tabular}


$\mathrm{m}^{-2} \mathrm{~s}^{-1}$ at the same day length as the experimental cultures.

Experimental cultures of $20 \mathrm{ml}$ volume were grown in $18 \times 150 \mathrm{~mm}$ Pyrex test tubes, which were kept in racks in water baths containing polyethylene glycol in a freezer without cover (temperature regulation by thermostats). Light was supplied from above, either by 2 Osram HQI-T $250 \mathrm{~W} / \mathrm{D}$ halogen dysprosium lamps $\left(50,70,200,350\right.$, and $\left.500 \mu \mathrm{mol} \mathrm{m} \mathrm{m}^{-2} \mathrm{~s}^{-1}\right)$ or fluorescent tubes (Sylvania warm white $22 \mathrm{~W}, \mathrm{~F} 15 \mathrm{~W} / \mathrm{WW}: 3,10$, 18 , and $33 \mu \mathrm{mol} \mathrm{m} \mathrm{m}^{-2} \mathrm{~s}^{-1}$ ). Light was attenuated by means of neutral nylon screens and by varying the distance between the lamps and the cultures. The cultures were grown at 4 day lengths (D): 10 and $24 \mathrm{~h}$ (all irradiances), and 4 and $19 \mathrm{~h}$ (irradiances of 50 to 500 umol $\mathrm{m}^{-2} \mathrm{~s}^{-1}$ only).

Scalar irradiance ( $\left.E_{0}, P A R\right)$ was measured in the tube racks with a QSL-100 quantum sensor (Biospherical Instruments). In vivo fluorescence was measured once per day (about $2 \mathrm{~h}$ into the light period) by inserting the test tubes into the flow cuvette of a Turner 111 fluorometer. Measurements were carried out for 7 to $12 \mathrm{~d}$ after an adaptation period of at least $4 \mathrm{~d}$. When in vivo fluorescence reached a reading of about 50 (relative units) for the $1 \times$ slit of the fluorometer, cultures were diluted by a factor of 20 with fresh medium. Readings of 30 to 70 relative units at the $10 \times$ slit of the fluorometer corresponded to about 9 to $20 \mu \mathrm{g} \mathrm{chl} \mathrm{a} \mathrm{l}^{-1}$. Dilution, when necessary, has been taken into account in the calculation of the growth rate (Sakshaug et al. 1984). On a semi-log plot, growth curves represent exponential growth at the $1 \%$ significance level when the Product-Moment Correlation Coefficient $(\mathrm{r})$ is $>$ $0.88(\mathrm{n}>7)$ for regressions of the natural logarithm of in vivo fluorescence vs time (Wardlaw 1985).

\section{RESULTS}

The maximum observed specific growth rates for each species varied within a relatively narrow interval, from $0.41 \mathrm{~d}^{-1}$ (0.59 doubl. d $\mathrm{d}^{-1}$ ) (Amphiprora sp.) to $0.60 \mathrm{~d}^{-1}\left(0.87\right.$ doubl. $\left.\mathrm{d}^{-1}\right)$ (Thalassiosira antarctica and T. bulbosa; Table 2).

All species except Chaetoceros furcellatus and Amphiprora sp. exhibited their highest growth rate in continuous light (Table 2). The latter 2 grew fastest at 10 and 19 h day length, respectively. Thalassiosira nordenskioeldii, Nitzschia delicatissima, and $T$. bioculata did not grow in a significantly exponential fashion at 4 h day length.

Growth rates were generally low $\left(<0.36 \mathrm{~d}^{-1}\right)$ at irradiances of $18 \mu \mathrm{mol} \mathrm{m} \mathrm{m}^{-2} \mathrm{~s}^{-1}$ and less, and at $3 \mu \mathrm{mol}$ $\mathrm{m}^{-2} \mathrm{~s}^{-1}$ were only 0 to $0.08 \mathrm{~d}^{-1}$ (Table 2). Photoinhibition, albeit little pronounced, was discernible in the 3
Nitzschia species at $500 \mu \mathrm{mol} \mathrm{m}^{-2} \mathrm{~s}^{-1}$, particularly in continuous light (Table 2).

Growth rates of all species increased up to 50 or 70 umol $\mathrm{m}^{-2} \mathrm{~s}^{-1}$, above which they were relatively constant, but depended on day length (Fig. 1). The average maximum growth rate for all species increased with day length from $0.16 \mathrm{~d}^{-1}$ at $4 \mathrm{~h}$ to $0.46 \mathrm{~d}^{-1}$ for continuous light (Fig. 2).

The relationship between growth rate $(\mu)$ and day length (D) was estimated by a nonlinear regression program based on an algorithm developed by Marquardt (1963):

$$
\mu=\frac{0.75 \pm 0.13 \mathrm{D}}{(15.9 \pm 0.56)+\mathrm{D}}
$$

This equation fits remarkably well to the average maximum growth rate of all species for each day length (Fig. 2) (Table 3).

ANOVA shows that the impact of day length upon growth rates was significant $\left(\mathrm{F}_{[3,33\}}=26.5, \mathrm{p}<0.0001\right)$. Taking the total variation among species into account, the standard deviation for observed vs predicted growth rates was $0.08 \mathrm{~d}^{-1}$.

ANOVA indicates no significant difference in growth rates ( 50 to $500 \mu \mathrm{mol} \mathrm{m} \mathrm{m}^{-2} \mathrm{~s}^{-1}$ ) between the 3 ecological groups at any day length $\left(4 \mathrm{~h}, \mathrm{~F}_{(2,23)}=0.14, \mathrm{p}<0.9_{\text {; }}\right.$ $10 \mathrm{~h}, \mathrm{~F}_{(2,23)}=1.05, \mathrm{p}<0.4 ; 19 \mathrm{~h}, \mathrm{~F}_{(2.46)}=0.91, \mathrm{p}<0.4$; $\left.24 \mathrm{~h}, \mathrm{~F}_{(2,44)}=1.67, \mathrm{p}<0.2\right)$.

\section{DISCUSSION}

The present results largely agree with results from field studies at low temperatures (Durbin 1974, Palmisano \& Sullivan 1982, Jacques 1983, Sakshaug \& Holm-Hansen 1986). Growth rates generally increased with irradiance up to 50 or $70 \mu \mathrm{mol} \mathrm{m} \mathrm{m}^{-2} \mathrm{~s}^{-1}$ (Fig. 1) and were quite independent of irradiance above that level. Saturation irradiances were similar to those published by Harris (1978) and Jacques (1983) for phytoplankton growth at low temperatures.

The maximum growth rate among all species was $0.6 \mathrm{~d}^{-1}$, which is close to the rate predicted for $-0.5^{\circ} \mathrm{C}$ by Eppley's (1972) equation for temperature-dependent growth $\left(0.57 \mathrm{~d}^{-1}\right)$. This may indicate that there are no particular adaptive strategies which allow arctic diatoms to grow faster than temperate species would do at low temperatures.

Phytoplankton respond to variation in the light regime by photoadaptive processes which serve to minimize variations in the growth rate when light is the major factor controlling growth (Sakshaug \& HolmHansen 1986). The negligible variation in growth rate at irradiances from 50 to $500 \mu \mathrm{mol} \mathrm{m} \mathrm{m}^{-2} \mathrm{~s}^{-1}$ indicates that the photoadaptive response in the above sense is flex- 
Table 2. Growth rates $\left(\mathrm{d}^{-1}\right)$ of Barents Sea diatoms at combinations of different scalar irradiances $\left(E_{o}, \mu m o l m^{-2} s^{-1}\right)$ and day lengths $(D, h)$

\begin{tabular}{|c|c|c|c|c|c|c|c|c|c|}
\hline $\mathrm{D}$ & 3 & 10 & 18 & 33 & $\begin{array}{l}E_{0} \\
50\end{array}$ & 70 & 200 & 330 & 500 \\
\hline \multicolumn{10}{|c|}{$T$ antarctica } \\
\hline 4 & - & - & - & - & $0.14^{a}$ & $0.16^{\mathrm{a}}$ & 0.20 & 0.15 & 0.16 \\
\hline 10 & 0 & 0 & 0 & 0.07 & 0.31 & 0.31 & 0.33 & 0.30 & 0.33 \\
\hline 19 & - & - & - & - & 0.46 & 0.52 & 0.53 & 0.58 & 0.30 \\
\hline 24 & 0.08 & $0.01^{\mathrm{d}}$ & $0.05^{d}$ & 0.33 & 0.60 & 0.59 & 0.58 & 0.48 & 0.51 \\
\hline \multicolumn{10}{|c|}{ I nordenskloeldii } \\
\hline 4 & - & - & - & - & $0.11^{\mathrm{a}}$ & $0.12^{\mathrm{a}}$ & $0.13^{\alpha}$ & $0.20^{\mathrm{c}}$ & $0.13^{\mathrm{a}}$ \\
\hline 10 & $0.02^{a}$ & 0 & 0.10 & 0.13 & 0.31 & 0.34 & 0.31 & 0.30 & 0.33 \\
\hline 19 & - & - & - & - & 0.29 & 0.27 & 0.39 & 0.44 & 0.43 \\
\hline 24 & $0^{\mathrm{a}}$ & 0.13 & 0.20 & 0.37 & 0.56 & 0.46 & 0.50 & 0.58 & 0.52 \\
\hline \multicolumn{10}{|c|}{ P. glacialis } \\
\hline 4 & - & - & - & - & $0.05^{\mathrm{c}}$ & 0.07 & 0.12 & 0.13 & 0.15 \\
\hline 10 & $0.04^{\mathrm{a}}$ & 0 & 0.08 & 0.17 & 0.30 & 0.29 & 0.25 & 0.27 & 0.26 \\
\hline 19 & - & - & - & - & 0.25 & 0.31 & 0.36 & 0.19 & 0.25 \\
\hline 24 & 0 & 0.16 & 0.10 & 0.42 & 0.40 & 0.24 & 0.32 & 0.38 & 0.35 \\
\hline \multicolumn{10}{|c|}{ N. delicatissima } \\
\hline 4 & - & - & - & - & $0.10^{\mathrm{a}}$ & $0.05^{\mathrm{a}}$ & $0.06^{\mathrm{a}}$ & $0.01^{\mathrm{a}}$ & $0.11^{\mathrm{d}}$ \\
\hline 10 & $0.02^{a}$ & 0.08 & 0.12 & 0.19 & 0.12 & 0.13 & 0.11 & 0.29 & 0.05 \\
\hline 19 & - & - & - & - & 0.35 & 0.44 & 0.42 & 0.34 & 0.30 \\
\hline 24 & 0 & 0.23 & 0.36 & 0.41 & 0.36 & 0.39 & 0.50 & 0.46 & 0.36 \\
\hline \multicolumn{10}{|c|}{$T$ bulbosa } \\
\hline 4 & - & - & - & - & $0.07^{\mathrm{a}}$ & 0.07 & 0.20 & 0 & 0.12 \\
\hline 10 & 0.02 & 0.07 & 0.12 & 0.20 & 0.31 & 0.38 & 0.34 & 0.32 & 0.32 \\
\hline 19 & - & - & - & - & 0.43 & 0.45 & 0.46 & $0.30^{\mathrm{a}}$ & 0.44 \\
\hline 24 & $0^{\circ}$ & 0.12 & 0.24 & 0.42 & 0.59 & 0.59 & 0.60 & 0.46 & 0.54 \\
\hline \multicolumn{10}{|c|}{$T$ bioculata } \\
\hline 4 & - & - & - & - & 0 & 0 & 0 & $0.12^{d}$ & $0.01^{\mathrm{a}}$ \\
\hline 10 & 0 & 0.05 & 0.07 & 0.11 & 0.16 & 0.15 & 0.19 & 0.23 & 0.19 \\
\hline 19 & - & - & - & - & 0.29 & 0.33 & 0.34 & 0.30 & 0.30 \\
\hline 24 & 0.03 & 0.19 & 0 & 0.38 & 0.42 & 0.40 & 0.30 & 0.43 & 0.34 \\
\hline \multicolumn{10}{|c|}{ C. furcellatus } \\
\hline 4 & - & - & - & - & 0.15 & 0.16 & 0.21 & 0.14 & $0.16^{\mathrm{a}}$ \\
\hline 10 & $0.05^{\mathrm{a}}$ & 0.11 & 0.14 & 0.23 & 0.37 & 0.37 & 0.41 & 0.49 & 0.30 \\
\hline 19 & - & - & - & - & 0.28 & 0.33 & 0.33 & 0.24 & 0.46 \\
\hline 24 & 0 & 0.10 & 0.15 & 0.38 & 0.42 & 0.43 & 0.39 & 0.42 & 0.31 \\
\hline \multicolumn{10}{|c|}{ Amphiprora sp. } \\
\hline 4 & - & - & - & - & 0.15 & 0.16 & 0.12 & 0.14 & $0.19^{\mathrm{a}}$ \\
\hline 10 & 0.04 & 0.11 & 0.09 & 0.22 & $0.12^{a}$ & 0.18 & 0.21 & 0.25 & 0.16 \\
\hline 19 & - & - & - & - & 0.41 & 0.39 & 0.41 & 0.39 & 0.37 \\
\hline 24 & 0 & 0.22 & 0.36 & 0.37 & 0.30 & 0.31 & $0.21^{a}$ & 0.35 & 0 \\
\hline \multicolumn{10}{|c|}{ N. grunowii } \\
\hline 4 & - & - & - & - & 0.10 & $0.03^{\mathrm{a}}$ & 0.16 & 0.15 & 0.17 \\
\hline 10 & 0.03 & 0.14 & 0.17 & 0.23 & 0.34 & 0.31 & 0.33 & 0.33 & 0.34 \\
\hline 19 & - & - & - & - & 0.44 & 0.43 & 0.45 & 0.41 & 0.28 \\
\hline 24 & $0.25^{\mathrm{a}}$ & 0.27 & 0 & 0.36 & 0.55 & 0.55 & 0.56 & 0.34 & $0.14^{\mathrm{a}}$ \\
\hline \multicolumn{10}{|c|}{$N$, vanhoeffenii } \\
\hline 4 & - & - & - & - & $0.07^{\circ}$ & 0.09 & 0.13 & 0.15 & 0.19 \\
\hline 10 & 0.04 & 0.07 & 0.09 & 0.15 & 0.30 & 0.38 & 0.34 & 0.37 & 0.26 \\
\hline 19 & - & - & - & - & 0.33 & 0.43 & 0.42 & 0.34 & 0.45 \\
\hline 24 & $0.02^{\mathrm{a}}$ & 0.20 & 0.27 & 0.37 & 0.28 & 0.41 & 0.51 & 0.29 & 0.19 \\
\hline
\end{tabular}




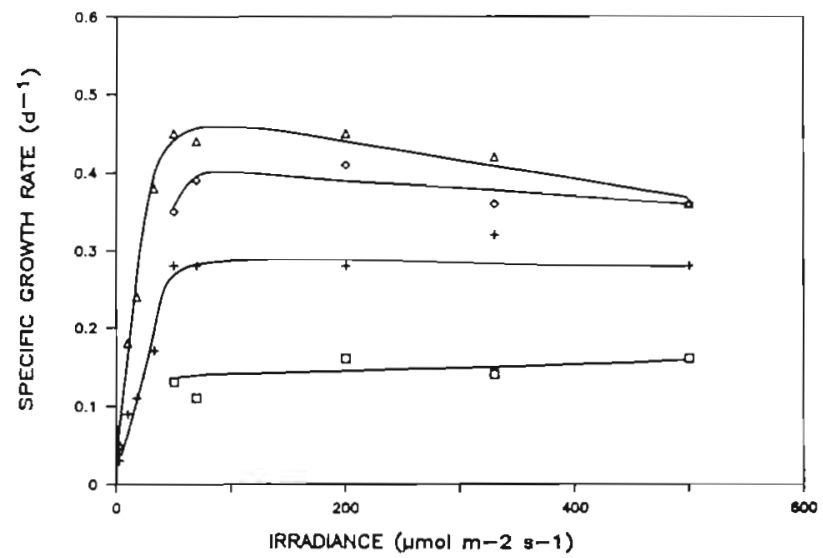

Fig. 1. Average specific growth rates $\left(\mathrm{d}^{-1}\right)$ of 10 Barents Sea diatoms vs irradiance ( $\mu \mathrm{mol} \mathrm{m} \mathrm{m}^{-2} \mathrm{~s}^{-1}$ ) at different day lengths. Curves drawn arbitrarily by hand. (a) $4 \mathrm{~h}_{i}(+) 10 \mathrm{~h}_{\mathrm{i}}(0) 19 \mathrm{~h}$; (ه) $24 \mathrm{~h}$

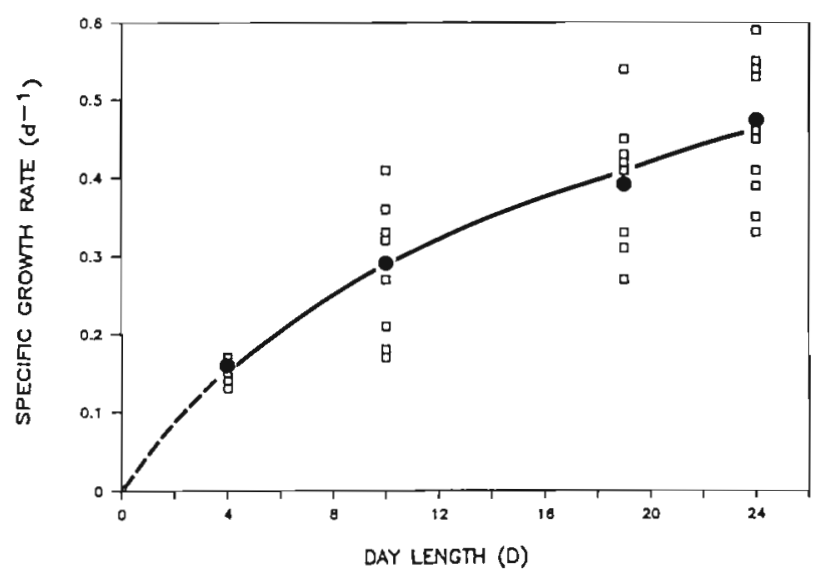

Fig. 2. Maximum specific growth rates $\left(\mathrm{d}^{-1}\right)$ of 10 Barents Sea diatoms vs day length (D). Curve represents Eg. (1); (•) average maximum growth rate for 10 species at each day length ible. This flexibility may, for instance, enable arctic diatoms living in a shaded epontic regime to grow well when exposed to strong light in the upper part of the sea during ice edge blooms, and may also explain why they occur in large amounts during spring blooms at the ice edge.

The growth rate increased progressively less with increasing day length. This result is similar to results for Fragilaria striatula and Synedra tabulata (Castenholz 1964), Dunaliella tertiolecta (Eppley \& Coatsworth 1966) and Ditylum brightwellii and Nitzschia turgidula (Paasche 1968). In fact, the average maximum growth rates for each day length can be described by a rectangular hyperbola. Thus arctic diatoms have a less flexible response to variations in day length than to variations in irradiance.

Growth rates and the level of light saturation are within the ranges that would be expected in temperate phytoplankton at low temperatures. Low temperatures apparently imply a decreased level of saturation and photoinhibition irradiance (Talling 1957, Palmisano et al. 1985). The present study does not indicate any particular physiological mechanisms which counteract low light or low temperature in phytoplankton from arctic waters in accordance with Harrison \& Platt (1986).

Arctic diatoms may, however, be particularly adapted to tolerate strong light in combination with long day and low temperature. Many temperate species are not able to grow under these circumstances (Sakshaug unpubl.), and other species are not able to grow at all in continuous light (Brand \& Guillard 1981). This may explain the absence of many temperate species at high latitudes.

There were no indications that the 3 different ecological groups have different growth strategies. The varia-

Table 3. Average maximum growth rates $\left(\mathrm{d}^{-1} \pm \mathrm{SD}\right)$ of Barents Sea diatoms for irradiances between 50 and $500 \mu \mathrm{mol} \mathrm{m}^{-2} \mathrm{~s}^{-1}$ at different day lengths

\begin{tabular}{lcccc|}
\hline Species & $4 \mathrm{~h}$ & $10 \mathrm{~h}$ & $19 \mathrm{~h}$ & $24 \mathrm{~h}$ \\
\hline T. antarctica & $0.17 \pm 0.03$ & $0.32 \pm 0.01$ & $0.54 \pm 0.03$ & $0.59 \pm 0.01$ \\
T. nordenskioeldii & & $0.32 \pm 0.02$ & $0.42 \pm 0.03$ & $0.53 \pm 0.05$ \\
$\begin{array}{l}\text {. glacialis } \\
\text { N. delicatissima }\end{array}$ & $0.13 \pm 0.02$ & $0.27 \pm 0.02$ & $0.27 \pm 0.06$ & $0.35 \pm 0.06$ \\
T. bulbosa & & $0.17 \pm 0.07$ & $0.39 \pm 0.05$ & $0.45 \pm 0.06$ \\
$T$ bioculata & $0.16 \pm 0.06$ & $0.33 \pm 0.03$ & $0.45 \pm 0.01$ & $0.54 \pm 0.07$ \\
C. furcellatus & $0.17 \pm 0.03$ & $0.18 \pm 0.03$ & $0.31 \pm 0.02$ & $0.39 \pm 0.04$ \\
Amphiprora sp. & $0.14 \pm 0.02$ & $0.41 \pm 0.06$ & $0.33 \pm 0.08$ & $0.41 \pm 0.02$ \\
$N$ grunowii & $0.16 \pm 0.01$ & $0.33 \pm 0.01$ & $0.39 \pm 0.02$ & $0.33 \pm 0.03$ \\
$N$ vanhoeffenii & $0.16 \pm 0.03$ & $0.36 \pm 0.02$ & $0.43 \pm 0.02$ & $0.55 \pm 0.01$ \\
Average maximum growth & $0.16 \pm 0.02$ & $0.29 \pm 0.08$ & $0.39 \pm 0.08$ & $0.46 \pm 0.07$ \\
rate of all species & 0.151 & 0.29 & 0.408 & $0.46 \pm 0.08$ \\
Estimated growth rates & 4.1 & 0 & 3.2 & 0.451 \\
Coefficient of variation $(\%)$ & & & & 1.4 \\
\hline
\end{tabular}


tions in growth rate are clearly larger within groups than among groups.

The results largely agree with growth rates recorded for cultures of ice algae from Antarctica (up to $0.4 \mathrm{~d}^{-1}$ at $46 \mu \mathrm{mol} \mathrm{m} \mathrm{m}^{-2} \mathrm{~s}^{-1}$; Palmisano \& Sullivan 1982) and growth rates recorded for cultures of pelagic antarctic diatoms (up to $0.49 \mathrm{~d}^{-1}$ at $80 \mu \mathrm{mol} \mathrm{m} \mathrm{m}^{-2} \mathrm{~s}^{-1}$; Sakshaug \& Holm-Hansen 1986).

Algae in the Barents Sea do not receive continuous constant irradiance. At $70^{\circ} \mathrm{N}$, day length increases from $9 \mathrm{~h}$ on 1 March to continuous light on 13 May. Considering the relatively low ability of algae to compensate for differences in day length, day length should have a strong impact on growth rates and should be important for the timing of the spring bloom.

Acknowledgements. This work is a part of PRO MARE and has been financed by the Norwegian Council for Science and Humanities and the Norwegian Council for Fisheries Research. We thank Dr E. Syvertsen and Prof. E. Paasche for supplying the cultures.

\section{LITERATURE CITED}

Brand, L. E., Guillard, R. R. L. (1981). The effects of continuous light and light intensity on the reproduction rates of twenty-two species of marine phytoplankton. J. exp. mar. Biol. Ecol. 50: 119-132

Castenholz, R. W. (1964). The effect of daylength and light intensity on the growth of littoral marine diatoms in culture. Physiol. Plant. 17: 951-963

Durbin, E. G. (1974). Studies on the autecology of the manine diatom Thalassiosira nordenskioeldii Cleve. I. The influence of daylength, light intensity, and temperature on growth. J. Phycol. 10: 220-225

Eppley, R. W., Coatsworth, J. L. (1966). Culture of the marine phytoplankter, Dunaliella tertiolecta, with light-dark cycles. Arch. Microbiol. 55: 66-80

Eppley, R. W. (1972). Temperature and phytoplankton growth in the sea. Fish. Bull. U. S. 70: 1063-1085

Grant, W. S. Horner, R. A. (1976). Growth responses to salinity variation in four arctic ice diatoms. J. Phycol. 12: $180-185$

This manuscript was presented by Dr H. R. Skjoldal, Bergen, Norway
Guillard, R. R. L., Ryther, J. H. (1962). Studies of marine planktonic diatoms. I. Cyclotella nana Hustedt, and Detonula confervacea (Cleve) Gran. Can. J. Microbiol. 8: 229-239

Harris, G. P. (1978). Photosynthesis, productivity and growth: The physiological ecology of phytoplankton. Arch. Hydrobiol. Beih. Ergebn. Limnol. 10: 1-171

Harrison, W. G., Platt, T. (1986). Photosynthesis-irradiance relationships in polar and temperate phytoplankton populations. Polar Biol. 5: 153-164

Hegseth, E. N. (1989). Photoadaptation in marine arctic diatoms. Polar Biol. 9: 479-486

Jacques, G. (1983). Some ecophysiological aspects of the Antarctic phytoplankton. Polar Biol, 2: 27-33

Marquardt, D. W. (1963). An algorithm for least squares estimation of nonlinear parameters. J. Soc. Industr. appl. Math. 2: 431-441

Neori, A., Holm-Hansen, O. (1982). Effect of temperature on rate of photosynthesis in Antarctic phytoplankton. Polar Biol. 1: 33-38

Paasche, E. (1968). Marine plankton algae grown with lightdark cycles. II. Ditylum brightwellii and Nitzschia turgidula. Physiol. Plant. 21: 66-77

Palmisano, A. C., Sullivan, C. W (1982). Physiology of sea ice diatoms. I. Response of three polar diatoms to a simulated summer-winter transition. J. Phycol. 18: 489-498

Palmisano, A. C., Sullivan, C. W. (1985). Physiological response of micro-algae in the ice-platelet layer to lowlight conditions. In: Siegfried, W. R., Condy, P. R., Laws, R. M. (eds.) Antarctic nutrient cycles and food webs. Springer Verlag, Berlin, Heidelberg, p. 84-88

Palmisano, A. C., SooHoo, J. B., Sullivan, C. W. (1985). Photosynthesis-irradiance relationships in sea ice microalgae from McMurdo Sound, Antarctica, J. Phycol. 21: 341-346

Sakshaug, E., Granéli, E., Elbrächter, M., Kayser, H. (1984). Chemical composition and alkaline phosphatase activity of nutrient-saturated and P-deficient cells of four marine dinoflagellates. J. exp. mar. Biol. Ecol. 77: 241-254

Sakshaug, E., Holm-Hansen, O. (1986). Photoadaptation in Antarctic phytoplankton: variations in growth rate, chemical composition and P versus I curves. J. Plankton Res. 8: $459-473$

Spies, A. (1987). Growth rates of Antarctic marine phytoplankton in the Weddell Sea. Mar. Ecol. Prog. Ser. 41. 267-274

Talling, J. F. (1957). The phytoplankton populations as a compound photosynthetic system. New Phytol. 56: 133-149

Wardlaw, A. C. (1985). Practical statistics for experimental biologists. John Wiley \& Sons, New York

Manuscript first received: October 18, 1989

Revised version accepted: April 5, 1990 